NBSIR 75-976

\title{
Standards and Measurement Capabilities in the Kingdom of Saudi Arabia
}

Dr. A. Allan Bates

Spring 1975

Final Report

Personal Report Concerning Consultation to the

Governments of the United States of America and the

Kingdom of Saudi Arabia

Prepared for

U.S.-Saudi Arabian Joint Working Group on Industrialization of U.S.-Saudi Arabia Joint Commission

(Under Auspices of the Office of international Relations, National Bureau of Standards) 


\section{STANDARDS AND MEASUREMENT CAPABILITIES IN THE KINGDOM OF SAUDI ARABIA}

Dr. A. Allan Bates

Spring 1975

Final Report

Personal Report Concerning Consultation to the Governments of the United States of America and the Kingdom of Saudi Arabia

Prepared for

U.S.-Saudi Arabian Joint Working Group on Industrialization of U.S.-Saudi Arabia Joint Commission (Under Auspices of the Office of International Relations, National Bureau of Standards)

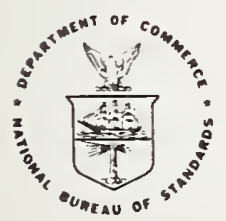

U.S. DEPARTMENT OF COMMERCE, Rogers C.B. Morton, Secretary James A. Baker, III, Under Secretary Dr. Betsy Ancker-Johnson, Assistant Secretary for Science and Technology 

Page

Introduction.......................... 1

Standardization........................... 1

The Building of a National Institution............ 2

The Problems (A Discussion of Origins)............ 3

SASO is a Law-making Body...................... 7

Field Observations, Plant and Laboratory Visits....... 8

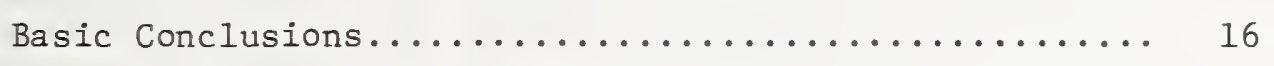

Recommendations, With Explanatory Notes........... 17

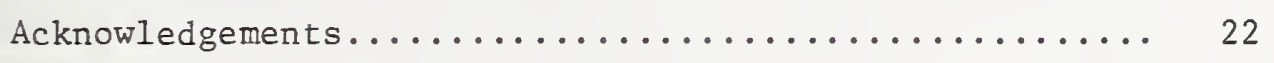

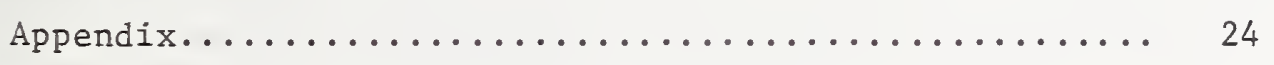



STANDARDS AND MEASUREMENT CAPABILITIES

IN THE KINGDOM OF SAUDI ARABIA

Personal Report by Dr. A. Allan Bates

Concerning Consultation to the Governments of the United States of America and the

Kingdom of Saudi Arabia (Spring 1975)

\section{Introduction}

This report will describe a series of visits and conferences with U.S. Embassy officials, Saudi Arabian Government and standards officials, industries, testing and control laboratories, building and construction operations etc. I will discuss and analyze existing problems and w111 make recommendations looking toward an efficient system of industrial and engineering standards and building codes for national use with harmonization where possible with existing and prospective regional and international standards. Recommendations w11 also deal with organization of national standardization offices and programs and with laboratory and inspection services needed.

\section{Standardization}

Standardization as a generic procedure involves a spectrum of related activities with loosely defined boundaries, widely misunderstood objectives and pervasive consequences. A standard is usually couched in technical terminology. But the ultimate uses and purposes of a standard are almost always economic, social, cultural, and political. Certainly, anyone who has worked much in the field of bullding codes knows that they are eminently political documents. The writing of standards does indeed require wide technological expertise; but a good set of standards w111 never be written by technical expertise alone. Any standard, to be useful, must be formulated, promulgated, applied and enforced within the limitations of the economic, social, cultural and political framework wherein 1t will be adopted.

Therefore an effective national standards organization must possess within its own personnel or within the body of its available advisors and assoclates not only the technical expertise but also adequate experience and competence in the economic, sociological, managerial, cultural and political aspects and consequences of 1 ts work so that it may predict what effects it will have on the life of the nation. This is most emphatically true when the national standards organization is given legal power to make its standards mandatory on the nation, as is the case with SASO, the Saud1 Arabian Standards Organization. 
A typical American or European building code comprises hundreds of everchanging, intricately inter-related standards embedded in a matri: composed of more hundreds of administrative rules, regulatory requirements, definitive classiflcations and special circumstantial appendices. So luxuriant an organism, nurtured through decades of scientific fertilization and technological cross-breeding in America or Europe cannot be transplanted directly to the soll of Saudi Arabla without drastic pruning and years of re-acclimatization in its new habitat.

The development and use of a bullding code involves the most complex and difficult of all standardization operations. The city of Los Angeles alone has over flve thousand trained building inspectors trylng to enforce the bullding code of that one city. So far as I could find out there is not a building inspector in all of Saudi Arabia, although doubtless there are individuals there who have the qualifications to become inspectors after they have recelved some months of intensive instruction and training.

Saud1 Arabla has embarked on a five-year program of industrial development. As of this writing the detalls of the program have not been announced officlally. It has, however, been reported in public print by economics writers of acceptable authority that, during the five years, capital spending of over one hundred forty billion dollars will be Involved.

As of the time of my sojourn with SASO (February-March 1975), that organization had apparently been given little or no advance information concerning the elements of the flve-year plan. Yet it is obvious that such information is necessary $1 f$ SASO is to plan 1ts own program of standards production most effectively. American or other forelgn advisors to SASO must also be thoroughly familiar with the contents and the projected timing of all parts of the program. A national system of standards, such as SASO is expected to produce, must be composed of a completely inter-dependent and coordinated array of individual standards. The standards mandatorily imposed upon or voluntarily adopted by Industry $X$ must bear a viable relationship to the standards used by every other industry which is a supplier to or a purchaser from Industry $X$.

\section{The Building of a National Institution}

Standards are a modern medium through which certain fundamental interests of governments, industries, communities, and individual citizens are coordinated and advanced for the common benefit of all.

In an industrialized society it may well be that the national set - or system - of standards by which that society lives and does Its work is 
no less important in shaping the society than are its laws. Often, of course, the standards and the laws are one and the same.

The organization or institution which develops the nation's system of standards must have deep roots in every stratum of the nation's economic structure. It must be not merely in contact with but actually an integral part of governments (national and local), of industries, of communities, and of the consuming groups of the individual citizenry.

The Saudi Arabian Standards Organization is too young to have become a truly national institution in the broad sense described above. This, however, is now its most important task. It wil1 not be accomplished easily or quickly. In any country national institution building must take place with due regard to national customs and concepts. But in every nation, however authoritarlan like the Soviet Union or nonauthoritarian like the United States, the national standards organization must be a living, vital organ of society recognized as necessary and beneficial to the 1 ffe and welfare of all.

For SASO such institution building will require constructive originality, flexibility and persistence of a high order to be effective in the unique economic context of Saudi Arabia today.

In my recommendations I will suggest limited steps toward this long range objective. I shall also make recommendations for short range progress which will lead toward accomplishment of the longer range purpose.

\section{The Problems (A Discussion of Origins)}

Historically, standardization arose as a result of industrialization and was, therefore, preceded by industrialization. The few important exceptions to this course of events have involved highly special cases of recent origin. In Saudi Arabia this "natural history" of standardization will be largely reversed. From this reversal come many of Saudi Arabian Standards Organizations most difficult problems.

Standards are not produced by the directors, managers, technical staff or other employees of standards organizations. The large numbers of men and women who work in the offices of the American Society for Testing and Materials (ASTM) do not produce the thousands of standards which ASTM publishes. The staff of the American National Standards Institute (ANSI) produces no standards. Neither are standards produced by the British Standards Institution (BSI), the Association Francaise de Normalization (AFNOR), the Deutscher Normenausschuss (DNA) nor even by the Standards Committee of the Council of Ministers of the Union of Soviet Socialist Republics (GOST). 
To cite a specific illustrative example which has a direct bearing on the work of SASO, the Committee on Cement (C-1) of ASTM has over a hundred and fifty members. I am one of those members who compose over twenty-five subcommittees of $\mathrm{C}-1$ each of which is responsible for some aspect of the standardization of Portland cements. The majority of the members of Committee $(C-1)$ on Cement are representatives of industrles which elther consume or produce cement. They are greatly assisted by representatives from universities, engineering schools, government agencles, research institutes, etc. Almost every member of Committee $(C-1)$ on Cement has access to a research or control

laboratory which w111 carry out experiments on cement at the member's request or order. It takes about two years on the average for Committee $\mathrm{C}-1$ to produce a standard. Occasionally this perfod has been extended to four or more years. In contrast, SASO has two men working on cement standardization with very little help from industry or anyone else apparently and they were expected to produce several standards in approximately a year!

The point I am making most emphatically is that industrial standards can be produced only with a great deal of coordinated work by industries and their appointed representatives. This is true not only in America but in Britain (BSI), France (AFNOR), Germany (DNA), and even in the Soviet Union (GOST). I know and have worked with 311 of these standards organizations and many others. It is of special interest that the Soviet Standards Committee which also produces mandatory national standards, as does SASO, depends very heavily on the expertise drawn from Soviet industries.

I have dwelt at length on standardization of Portland cement (and will return to it later) because 1 is is one of only two products produced in Saudi Arabla by manufacturing industries operating on a massive scale to meet a vital consumer need. The other product, of course, is oll. It may be further sald with some reason that there are only two nonservice industries of notable size in Saudi Arabia: (1) petroleum and (2) construction. And, in nearly all Saudi bullding and construction of much consequence Portland cement is the vital ingredient. It is therefore the most important industrial product on which SASO can gain procedural experience.

In order to lay the groundwork for a basic recommendation which I shall make later, I shall go on here to clte further statistics relating to the standardization work of ASTM. Since Portland cement is essentially just an adhesive used to bind other materlals together, It will be instructive, relative to SASO's interests, to pursue the question of these other materials and products which combine with cement and note how they (as materials and as products) are standardized. Much the most important of these materials are sands and gravels of which Saudi Arabla has native supplies perhaps in 
superabundance. When combined properly with cement the products are called "concrete", and there is a variety of standardized engineering concretes. Committee C -9 on Concrete of ASTM has about two hundred and twenty- five members working on over thirty subcomittees. Certain members of Committee C-1 on Cement, 11ke myself, are also members of $\mathrm{C}-9$. The purpose of this dual membership is to assure that the standards of the two committees shall be compatible and sultably coordinated. There are also ASTM committees on asbestos-cement products, on concrete pipe, on mortars for concrete masonry, on concrete aggregates etc. Each of these committees has appropriate liaison with the others through dual membership, as between $C-1$ and $C-$ 9. The committee $A-1$ on Steels has over four hundred members, the Comittee D-2 on Petroleum Products over three hundred, the Committee D-13 on Textiles about four hundred and fifty, the Committee D-20 on Plastics about four hundred and fifty, etc.

As is the case with Committee C-l on Cement, the majority of these many thousands of ASTM standards comittee members are provided by industries which have the technical expertise and the economic experience (production costs, customers' technical requirements, competitive price ranges, etc.) which are absolutely necessary for producing a useful system of standards.

As a former president of ASTM, I made a brief study and estimate some years ago of the man-hours and the dollars which went annually into the production of ASTM standards. The hours added up to millions and the dollars to tens of millions.

It is self-evident that Saudi Arabla will not possess for many years to come any such pool of industrial and englneering experience to be drawn upon (by SASO) for purposes of developing standards. This brings me to my first recommendation which is so obvious as to seem almost superfluous. The experfence which Saud1 Arabla (and SASO) does not have, and cannot have in the near future, does exist and has for years been effectively organized to produce standards in the United States and other countries. The standards and codes thus already formulated are avallable to SASO for immedlate adoption and promulgation. This, of course, is exactly what SASO has been attempting to do in an extremely cautious way since 1 t was organized in 1972. The ultra-cautious and diffident attitude of SASO to its work is entirely understandable but is not, in my opinion, justified or tenable. If Saudi Arabia is going to establish a hundred billion dollar industrial complex in the next few years, it must have an appropriate system of industrial standards very soon. SASO is the only implement avallable by which to produce that system. Knowing that, however inadequate are the conditions under which 1 t must labor, its standards are nevertheless vital to the KIngdom, SASO should proceed boldly to adopt from existing sources a considerable 
number of basic industrial standards. These it should promulgate as "Tentative SASO Standards," a title and a procedure which I shall explain later as one of my recommendations.

No standard is ever final. Developing technology or changing economic conditions will always require constant re-examination of every standard. ASTM Committee $\mathrm{C}-1$ on Cement wrote 1 ts first standard on Portland cement seventy years ago and has been modifying and elaborating it ever since. Such is the experience of all standardization organizations.

Saudi Arabia is in the beginning stages of national industrial revolution. The course of a standard in such a period is like the flight of a falcon in a desert windstorm. Industrial and economic turbulence of exceptional intensity must be expected during the next decade of the nations development program.

The developing nations which currently occupy so much of the world's attention are, almost by definition, nations which exhibit a shortage of capital combined with an accumulation of available labor. Saudi Arabla is the one notable exception; with its huge excess of capital and its unparalleled shortage of labor, this country is a phenomenon unique in world economic history. Furthermore this unprecedented phenomenon burst upon the economic world almost overnight and without effective warning - as result, not of normally predictable natural discoveries or scientific developments, but as the outcome of a commercial decision. These facts are, of course, all well known but, what is appreclated by very few, is that they confront SASO with an array of standardization problems never before encountered in the history of industrial standardization.

SASO stands alone - almost completely without the extensive industrial participation, the scientific research facilities, the practical economic experience, the supporting national body of professional engineers or an adequate system of Saudi universities and technical institutes to draw upon, all of which the great standardization organizations of other nations depend upon and without which they could not function. In an operational sense SASO in these early years of its existence must be a self-made institution working according to self-determined unprecedented modes of procedure. Inevitably SASO will make some mistakes. Standardization is not an exact science, especially in the dynamic realm of modern industry. Even the oldest and most experienced standards organizations make mistakes and have established methods for rectifying them such as Boards of Appeal, etc. I shall discuss these later in connection with "consensus standards." 


\section{SASO is a Law-making Body}

The standards which SASO produces and causes to be published become mandatory in the Kingdom of Saudi Arabia. This is an extremely grave responsibility to place on the shoulders of so young, so small, and so inexperienced an organization. Although the responsibility simplifies SASO's work in a certain sense, it also makes the work much more difficult by imposing a heavy psychological burden. It is somewhat like placing a young and inexperienced man in the position of General Manager of a new, complicated industrial plant which is seriously short of trained workers and telling him: "you are going to be held responsible for making this plant fully productive very quickly and since all your orders will be final and decisive, you must always be right."

The Constitution of SASO is contained in Royal Decree No. M/10 dated 3-3-1392 H (which corresponds with 16 April 1972). The wording is as follows :

"ARTICLE FIVE. Compliance with (SASO) standards is mandatory. By (SASO) Board of Directors' decision, certain specific national standards or classes of national standards may be voluntarily complied with....

"ARTICLE SIX. All ministries, Independent agencies, and governmental organizations shall adopt the (SASO) mandatory national standards as a basis for their purchase specifications and for all their activities."

It is interesting that the Decree does permit the SASO Board of Directors to make certain exceptions to the absolutely mandatory aspect of SASO standards - but not in the case of use by government agencies. The Board must use its powers of exception sparingly if it is to avoid creating some costly and disruptive confusion. I shall discuss this later. Nevertheless the Board's power of exception is a wise and helpful provision.

In emphasizing the gravity of the mandatory, legally enforceable character of SASO's standards and the problems which that may create, I do not imply that some other standardization system would be better. At this time I do not believe that any alternative would be practicable in the Saudi Kingdom.

In this section of my report, I have dealt in general terms with certain elements of the current national situation in the Ringdom which have the effect of complicating or impeding SASO's productivity. The specific problems which originate in this combination of situational elements w11l require unusual or unique solutions. As industrialization of the Kingdom progresses, both problems and 
solutions w1ll change. SASO's tactics and procedures will therefore have to exhibit considerable flexibility. Planned adaptability will be required.

\section{Field Observations, Plant and Laboratory Visits}

The recommendations which I shall make in this report derive largely from the general circumstances which I have discussed above but are also affected by particular observations which I made in various locations as described in this section. It seems in order therefore to discuss these observations at this point.

\section{A. Building, Construction and Architecture}

In the capital city of Riyadh there is a high proportion of public structures all built basically of Portland cement concrete and exhibiting interesting architectural variety. The buildings of the state ministries are particularly prominent, each showing some Individualistic design incorporating features of traditional Moslem architecture. It is fortunate that Portland cement concrete lends Itself with extraordinary versatility and economy to construction of a prominent aspect of Eastern hot-climate architecture, the open, multitiered arcade and colonnade. One mold used over and over again can produce an arcade of great length. The savings in labor and materials thus achleved can be very large.

I was told that these large public structures are in major part designed and built under the supervision of foreign contractors who tend to use the methods and standards of their own respective countries. Since Article Six of the SASO Constitution declares that "All ministries.... and governmental organizations shall adopt SASO mandatory standards....etc," it seems that governmental policies and practices may have to be reviewed when a "National Saudi Arablan Bullding Code" is made operative. This should be a matter of study by SASO.*

Relative to private building and construction, I was informed that some building regulations had been promulgated a few years ago but that they had been Ineffective and are now generally disregarded. Another informant said that these regulations are non-existent today. Still another informant sald he did not belleve that such regulations had ever existed. I encountered such disagreement on many subjects into which I inquired. This difficulty probably arose in part from language differences, or from my not having addressed my questions to authoritatively informed persons.

In any case, private building apparently simply follows traditional patterns subject to only few public regulations or rules. However,

*Note: This recommendation is not explicitly restated in the section on recommendations. 
when one compares construction in the newer parts of the city with that in the old part, it is evident that some regulation is in effect in some areas.

Construction practices and building designs are conservative. Highrise buildings are being erected in the cities but are not yet numerous. They seldom exceed ten or twelve stories in height and generally consist of a cast-in-place reinforced concrete frame, flatplate floors and masonry fill-in walls both exterior and interior. The concrete form-work is simple, hand-constructed of re-used timber and frequently rather crude though fairly sturdy. The masonry walls may be of ceramic tile or concrete block of rather rough quality. The entire structure is usually covered with stucco and painted. Stucco and plaster work, an old art in the Arab World, is well done with many pleasing variations in form, coloring, and ornamentation.

Lower buildings, even the customary two- or three- story private dwellings of the upper class are usually constructed in much the same way except for a somewhat more extended use of concrete masonry. All private dwellings are surrounded by high stuccoed masonry walls, an almost invariable custom in Eastern countries. The quality standards for the masonry units, if they exist, are not very high. Roofs of all except a few of the more individualistic institutional buildings are flat since there is little rain and no snow to shed. Door and window frames are usually of wood, marble, or steel while sills, stairs, interior floors, etc., are most frequently some form of terrazzo.

In short, all structural aspects of all non-public buildings and even of most public ones are so uniform and so conventional that they could be covered by a rather simple set of building regulations - a starting point for a building code and an area of building technology in which the training of inspectors would be useful and effective in a fairly short time.

The service facilities, plumbing, heating and cooling, electrical installations and especially sanitary provisions would probably be more complicated. Such bullding supplies are imported from many countries and are consequently very diverse in dimensions, fittings, modes of installation, operation, economy, safety aspects, etc.

In Riyadh I watched intermittently for about a week the digging of an excavation for septic use by a large new private home in a residential quarter. The hole, about three meters square and two meters deep became about half full of an opaque green water of unpleasant appearance and odor. This apparently occurred by subterranean seepage and quite probably involved flow from the septic systems of surrounding houses. I was told that this is not an uncommon occurrence. It seems probable that a public health hazard could be 
the result. Similarly the condition of many of the city streets raises health questions. All of Riyadh gives the appearance of a vast continuous building site in the grip of a construction boom. No building site is ever of attractive appearance with its confused clutter of rough construction materials and debris. In Riyadh the extreme shortage of manpower and equipment causes incredible disorder. Vacant lots are piled high with construction rubbish to which has been added huge accumulations of garbage and cast-off wastes of household and commercial origins. The first step toward effective imposition of a building code in Riyadh and other Saudi cities must be a wellplanned, arduous, continuous and expensive campaign of public education in the basic elements of public hygiene. This is probably made particularly difficult by the movement into the cities of people from the small towns, villages, and camps of the desert. The intense desert sunlight is a potent cleanser but it cannot do its hygienic work in the crowded cities. I have encountered this problem in Sao Paulo and in Rio de Janeiro, in Caracas and Lima, in Calcutta and Manila. It is the central social problem in all hot-climate lands where country people flock into developing cities. The Saudi officials are aware of it and with the great new Saudi wealth are in a better position to undertake the basic educational effort than are most governments. It must - I repeat - precede the development and promulgation of building codes.

\section{B. Industrial Visits}

Industrial standardization cannot succeed without the cordial, continuous and intimate participation of the industries concerned, both producers and consumers. I use the word "consumer" here to include industries which utilize or "consume" the products of other industries, as the construction industry "consumes" cement, steel, electrical fittings, etc. When, as in Saudi Arabia, a standards organization (SASO) is required to publish standards for industries which do not yet exist in Saudi Arabia, provisions must be made for consulting those industries when they do come into local existence. The "Tentative Standard" is such a provision as I shall point out later.

I had planned to visit some representative industrial plants in the Kingdom. It soon was clear that both the need and the opportunities for doing this were quite limited. The oil industry and its satellites are self-contained from the viewpoint of standardization. The only other large product industry group of current concern is construction and its associated satellites of which the Portland cement producers comprise the only large segment. There are three cement plants in the Kingdom, one in each of the cities of Riyadh, Jidda, and Dharan-Damman. They are of roughly equal size and 
character. I chose to visit first the Riyadh plant of the Yamama Cement Company and later, if feasible, the plant in Jidda.

Accompanied by Mr. Sami Mirza, Manager of the Construction Standards Section of SASO, I was graciously received by the General Manager of Yamama (an Englishman), the Production Manager (a Syrian), and the Chief Chemist (an Egyptian), a11 of whom spoke English well. With these plant officials, I discussed the purposes of my visit and the manner in which I would like to inspect the plant. (I have spent countless days in scores of cement plants in dozens of countries). They agreed without reservation. I will sum up my observations and conclusions. The plant is of orthodox design (German built) with no exceptional features. The lime rock quarry is very close to the plant and yields a white limestone low in silica, alumina, and iron. These components which are necessary in Portland cement, although only in relatively small quantity, are brought from another quarry a few miles away. The lime rock looks much like the high-grade cretacious chalks and Iimestones used extensively in England and Western Europe for cement making. Since there is little overburden and the rock is easily quarried the plant's raw materials costs should be very low. The only other substance used extensively in making cement is fuel (oil, gas, or coal) with which the Kingdom is of course uniquely well and cheaply supplied. The plant's operations, crushing, grinding, raw-feed mixing, burning, clinker comminution, bagging, storage, etc. are all of customary character. Plant controls are not of the most modern type but are adequate. Shipping is either by truck or rail, facilities for both being extended into the plant. A worker's village (w1th mosque) lies very near the plant, quite probably on company property.

The control laboratory is equipped with all necessary sampling, conditioning and testing facilities - not entirely of latest type but quite adequate if well maintained. The lab crew, about a half dozen young men, mostly non-Saudi in appearance probably had subprofessional qualifications - but this is customary. Cement plant control testing is routine and can be taught to any normally bright young person under the guidance of a competent chemist - which the chief chemist of this plant quite certainly is. I did not request permission to examine the test records (some plant chemists are reluctant to show their records to strangers) so I did not see the actual history of plant performance.

My first conclusion: The Yamama Cement Company is capable of producing cements meeting the standards in general use internationally.

My second conclusion: The officials of the Yamama Cement Company, if properly and cordially cultivated by SASO can be SASO's most useful 
allies in the development of industrial standards at this time (useful generally - not just relative to cement).

In ny discussions with the Yamama Cenent Company officers, I received some impressions which are relevant here:

(1) They do not feel that they are given a reasonable voice or influence in SASO's procedures or in the standards which may be produced which concern them.

(2) They doubt (my deduction - not their statement) that the staff of SASO as presently constituted has had the intimate and extensive experience in actual cement production necessary to the development of cement standards for Saudi Arabia. ( $I$ agree but I would add that the staff of SASO should not be expected to have such experience - they should utilize the experience of the industry itself.)

(3) They expect the present very great denand for cenent in the kingdom to grow even greater and they have well-advanced plans to more than double plant capacity as soon as possible. (It is difficult to see how any foreign cement could compete in the Arabian market if the Saudi cerient companies are well managed.)

\section{Laboratory Visits}

The "Ouality Control Laboratory" in Dharan-Damman. This laboratory is devoted mainly to analyzing foods and drugs imported through the local harbor and customs house. One small room of the laboratory, however, houses a 50,000 pound Avery (English) tensile testing machine used for quality control of imported steel bars for concrete reinforcement. The operator has adapted the machine also to do standard bend tests (ductility) on reinforcing bar. The laboratory also has a steel hardness tester, penetration type, German made. The operator, a young Egyptian (speaks English), is obviously competent. The Avery company calibrates the tensile machine "about once or twice a year" with their own proving rings. The machine gets "a great deal of use" (the records corroborate this) but "has never gone seriously out of calibration."

I examined all test records of the last six months covering hundreds of shipments of steel from about twelve countries. There was no case of failure to meet established standards. Evidently no foreign producer is dumping sub-standard steel into Saudi Arabia. I have seen some unbelievably inferior steel dumped into other developing countries (mostly Latin America). It would be useful if Saudi Government authorities were to realize that this "dumping" is not happening in their country probably because it is widely known that 
they apply fair and competent testing according to internationally recognized standards.

This is an appropriate point at which to emphasize that a standard is only as good as the testing and inspection services by which it is enforced. This is notably true with regard to bullding codes.

I was informed that in Jiddah there is a steel inspection laboratory almost identical with the one in Dharan-Dammam. My plans to visit the Jiddah laboratory were cancelled by unforeseen circumstances.

Materials Testing Laboratory of the (DPW) Department of Public Works, Riyadh. A half-day visit to this laboratory was a most encouraging experience. It is the only generalized physical testing and research facility in Saudi Arabia capable of providing the necessary technical support for prospective SASO standards in the broad field of engineering materials. Such support for SASO is not a prescribed function of MTL-DPW; nevertheless, all of the test and research work carried out there is potentially useful to Saudi standardization progress. An immediate (and somewhat amusing) case of such usefulness arose in the course of my conversation with Dr. Shams-al-Din (Egyptian Director of MTL-DPW). I mentioned to him that the Yamama Cement Company was using a test for cement-mortar strength based upon a British standard which required the use of a certain standard sand from a precise British source. Yamama was therefore shipping sand to Arabia from England! However, MTL has now completed a research project by which sands from chosen Arabian deposits are equated with, and therefore substitutable for, the standard British sand. Since for years to come SASO is necessarily going to derive its standards from foreign sources and adapt them to Saudi conditions a long series of similar research projects will be required. Such projects are usually not difficult but they must be carried out in Saudi Arabia under the direction of scientifically and technically trained leaders who understand the differing effects of varying test conditions. A planned program of such tests should be laid out well in advance of the promulgation of any series of Saudi standards and SASO must be the central agency in planning the program. I was assured that the MTLDPW would be available to SASO for laboratory work required in such a program within limits compatible with MTL's other duties and responsibilities.

The MTL-DPW has (March 1975) a staff of about 28 scientists (mostly Egyptian) and 20 technicians. The laboratory is excellently equipped to carry out test and research work on a wide variety of building materials. 


\section{The Saudi Arablan Standards Organization (SASO)}

Within a few months after it had been constituted in Apr11 1972, SASO laid out a program of standards which it intended to produce and publish by July 1974. It was a large program covering many different subject areas. In April 1975, SASO's first standard was about to go into effect. This striking difference between declared program and actual performance does not, In my opinion, reveal in any meaningful sense, a failure by SASO. What it indicates most convincingly is that practical experience in the production of industrial standards was almost completely lacking in the Saudi Kingdom when SASO was concelved, authorized, and funded by the Saudi Government.

To have accomplished the 1972-1974 SASO program of standards production in accordance with the admirable SASO consensus procedures would have required a staff at least three times as large as the actual SASO staff of April 1975. Furthermore, not less than half of this staff would have had to be comprised of professional secretaries, competent typists, proficlent multi-lingual librarians and translators, and trained file clerks, all of whom are almost unobtainable in the Kingdom under current circumstances. These auxillary service workers comprise the actual operating mechanism of any consensus standards organization. Highly trained staff of scientists and engineers provide the guiding intelligence, the public authority and the administrative direction.

The "Guide to the Procedures of Saud1 Standards Preparation" which was given to me to study sets forth from twenty-five to forty successive operational steps collectively demanding professional correspondence, accurate filing and cross-filing, voluminous typing, preparation of minutes of meetings and a great deal of technical translation, all required or strongly suggested in the preparation of every SASO standard. Even if SASO had had the requisite professional and auxillary staff to have carrled out the proposed 1972-1974 program, my experfence indicates that the present state of postal, telephonic, telegraphic, and transportation services in the Kingdom would have serlously impeded SASO success in the effort.

The consensus principle is the working basis of every existing standards organization. The principle is sometimes partly disguised and it is used with varying rigor and in different modes by different organizations. The purpose of consensus of course, is to achieve agreement by every concerned party to the substance and the wording of any standard which may affect the interest of those parties. However, concerns vary from vital to marginal in character; not all concerns, therefore, can be accorded equal welght or validity. Hence the American National Standards Inst1tute (ANSI) describes standards 
consensus thus: "Consensus requires much more than a simple majority but not necessarily unanimity."

Perhaps the most difficult and most sensitive step in the entire field of standardization by consensus is the determination of the point at which effective, viable consensus of a character most conducive to community or national welfare has been achieved. This determination must be founded upon rigorously impartial judgment which is informed and tempered by vast experience in the restless world of industry, commerce, consumer welfare, national economic progress and political practicality. Such judgment cannot be quickly or easily acquired, nor, since it is in great demand, is it readily available.

It will be useful, I belleve, to describe the manner in which the American National Standards Institute (ANSI) reaches an acceptable judiclal decision on the point at which appropriate consensus has been reached on any and every standard. A Board of Standards Review appointed by the President and the Board of Directors is composed of fifteen individuals of long and varied experience in standardization. The Board operates as follows: "The members of the Board of Standards Review (BSR) shall be appointed to serve as individuals, not as members or representatives of an organization. Their competence and ability to render impartial judgment in the approval or withdrawal of American National Standards shall be the major criteria for appointment." Also: "Approval of a proposed standard as an American National Standard is the judicial determination that a consensus exists of those substantially concerned with the scope and provisions of the proposed standard." (From the "Operating Procedures of the Board" of Standards Review.")

The BSR is served by a special staff of highly competent technical secretaries who provide the Board with a complete annotated history of every standard which is proposed for ANSI acceptance as a National Standard. The BSR meets about eight times a year at ANSI headquarters in New York. At about half of these meetings it hears an appeal against a previous Board decision on a standard on which the Board has already taken action. These appeal sessions are announced well in advance and any concerned organization may attend and present its arguments on a case under consideration. After the BSR has made its judicial decision on an appealed case st111 another and final appeal may be made to the ANSI Board of Directors for a reversal of the BSR decision. In the five years during which I have been a member of BSR none of its judgments has been reversed even though some very powerful organizations have made appeals.

I have discussed the ANSI Board of Standards Review at some length in order to emphasize the very important fact that any standards 
organization which operates on the consensus principle (as SASO attempts to do) must eventually realize that the merits, the usefulness and the acceptability of any standard are found quite as much in the fairness and the equitability of the standard as in 1 ts technical quality. The Board of Standards Review never examines the technical merit of a standard. It considers only the judicial aspects of the procedures by which the standard has been developed.

It is doubtful that there could be found in the Saudi Kingdom today a group of individuals with sufficient experience in industrial standarilization to form a "court of appeal" such as the ANSI Board of Standards Review. There is some intimation in the SASO "Guide to the Procedures of Saudi Standards Preparation," that the SASO Board of Directors might act in that capacity. In view of the mandatory (lawmaking) powers of SASO this may not seem inappropriate and may be inevitable. However, the complete dominance of the Board by ministries of the national Government makes such use of the Board incompatible with consensus standardization in a free enterprise industrial soclety such as Saudl Arabla is vigorously attempting to establish.

The "Guide to Procedures, Formulation and Editing of Saudi Standards" has a number of clauses and phrases (English version) which permit elimination or evasion of various procedural steps at the discretion of the SASO staff. For example, on Page 1 of the Guide is written: "One or more of these procedures may be overstepped according to the type of the standard." In other cases a procedural step is ordered"if necessary...." or "if there is a need to...." Such confidence in staff discretion is good managerial psychology but it does leave. anyone outside of the staff (such as myself or other forelgn advisor) confused and uncertain in his attempts to evaluate SASO practices.

\section{Basic Conclusions}

(1) The Saudi Arabian Standards Organization is working under extremely difficult circumstances, which put severe limits on the Organization's productivity.

(2) The Organization is encountering unique problems for which there is no close precedent in the history of standardization.

(3) The problems are grouped roughly according to two different time scales:

(a) Short-range problems (3 months to 18 months)

(b) Long-range problems ( 1 year to $5+$ years) 
The short range problems result in large part from the speed with which the Saudi Kingdom is becoming transformed into an urbanindustrial state. The educational system is totally unprepared to meet the demands of such a transformation. Education is not a commodity which can be bought at a quick bargain sale. Excepting petroleum and mineral engineers, probably no more than a hundred welltrained engineers a year, now or in the next few years, can be developed in Saudi Arabia. SASO plans cannot anticipate more than a share in the severely limited avallable Saudi resources in welltrained engineers.

(4) The SASO operating procedures for development of industrial standards, while admirable in principle, are desiened for a longestablished, well-staffed standards organization working, within a nation of advanced industrial experience and capacity. The SASO procedures are therefore not practicable at this time in Saudi Arabia.

Recommendations, with Explanatory Notes

\section{A. Short Range}

1. SASO should immediately prepare and operate according to a set of "Interim Procedures" which lead to the issuance of "Tentative Standards" for immediate use in the Kingdom.

Explanation: The "Tentative Standard" is a device which has been used by many competent standards organizations. ASTM has employed it for many years. A "Tentative Standard" is not to be regarded as an incomplete or inferior standard. In its technical aspects it is as complete and as sound as any nontentative standard; but is issued for use in a situation wherein lack of experience suggests that currently unknown and unpredictable factors or difficulties may arise from its use. If, after one or two years, no such difficulties appear, the "Tentative" is then re-published as a regular standard. In view of the Saudi situation, where industrial experience is so generally lacking the Tentative Standard should be particularly useful. Whether a "Tentative" should be made immediately mandatory or after a period of say, a year would be a matter for judgment. In any case, all parties concerned with or affected by the "Tentative" must understand its nature and must keep adequate records concerning their experiences in its use.

The "Interim Procedures" to be immediately used in SASO operations must be greatly simplified as compared with the Procedures described in the present SASO "Guide to the Procedures of Saudi Standards Preparation." The latter should not now be changed but should remain in use where the case justifies them. When any standard is published by SASO it should be made clear whether it has been developed by Interim or by Regular Procedures. 
The "Interim Procedures" should be such as to permit sASO to adont immediately and with a minimum of consultation with other organizations any standard of such reputable origins and of such wide use as to guarantee its excellence. As example, the AST standards for Portland cement have enjoyed that status for nearly three quarters of a century. Those standards could imnediately be declared as official "Tentative Standards" in the Saudi Kingdom without fear of. unfortunate results. Py the same method many other standards could be quickly taken from sources such as ANSI, BSI, IEC, ISO, etc., solvinf, SASO's most pressing short-range problem which is to produce a significant number of important standards within the next few months. To accomplish this SASO may require the services of a small number of standards experts from heavily industrialized countrles durins the next 3-to-18 months. I would so advise but I believe it should he a matter for SASO's decision after they have considered this recommendation for Interim Procedures and Tentative Standards. The Egyptian technical experts who were with SASO) when I was there are excellent men but they were too few in number, too narrow, collectively, in industrial experience and insufficiently supported by auxiliary service personnel to be really effective in carrying, out this Recommendation.

2. SASO should take no action and spend no time or effort on the subject of Building Codes during the remainder of the year 1975 unless specifically requested in writing to do so by one or more of the ministries directly engaged in building, and construction or in nublic health and safety.

Explanation: The subject of Building Codes and Rerulations is in a hiohly confused state in the Kingdom. From my many conversations on the matter and from reports which $I$ have seen it is evident that committees have been organized and work has been done relating, to building regulations in fairly recent years. Little or nothing seems to have resulted from these efforts. I am convinced that nothine. effective can be done until a forceful Government campaign of national education on public hygiene and safety has been carried out. Until that has been done I belleve that any attempt to enforce a buildin? code will appear unfair and ridiculous to the better educated Saud 1 citizens. A building code is complex law aimed primarily at protecting public safety and public health. It may contain or refer to more than a hundred individual standards and when the time comes to develop a code SASO will be called upon to provide those standards. It will do so by direct adoption of standards already existing liowever, until the Saudi Government and the Saudi people are educated to realize the need for building codes SASO can do nothing very useful about them. SASO at this time has much more important and urgent work to do. 


\section{B. Lons. Range}

1. SASO should as soon as possible invite and urge the companies which comprise the Portland cement industry in Saudi Arabia to form the nucleus of a "Standing SASO Comittee on Portland Cement Standards" under SASO sponsorship, with the understanding that major and responsible consumers of cement are cordially welcome also to membership on the Committee.

Explanation: The Saudi Portland cement industry offers an ideal opportunity for SASO to improve and practice its consensus procedures so that SASO can become a productive body far into the long range industrial future which the Kingdom is planning.

The American Society for Testing and Materials (ASTM) consists of a staff of about two hundred and fifty employees and approximately seventeen thousand members. The members are grouped into many hundreds of technical committees for the purpose of writing standards. The members are the voting representatives of all the producers, consumers, government agencies, universities, research institutes etc., who have a responsible interest in standards. These members, in their technical committees, produce all of the thousands of ASIR standards. The staff employees of ASTM provide all the secretarial and office services required by the technical committees but these employees produce no standards. Every technical comittee is a standing (that is, permanent) committee and meets at least once a year (usually twice a year) in some city in the United States or Canada. At each meeting of every committee a staff employee of ASTM is present to act as secretary and to interpret any ASTM rules of procedure about which questions may arise. ASTM originated this Society structure in about the year 1898 and it has become the basic pattern followed in its essential features by every major standards organization in the world. The technical committees of ASTM include nearly two thousand representatives from approximately one hundred foreign countries (the actual figures vary, of course, from year to year and I make no attempt to keep accurately informed about them). I am convinced that ASTM is the most instructive standards organization in the world of which SASO could become a member and I urge SASO to do so at an early date.

Each of the three Portland cement companies of Saudi Arabia is in position to take a strong and useful part in a SASO Technical Committee on Portland Cement. Each has the necessary qualifications which are: 
a. a capable engineering and technical staff

b. a vital interest in industrial standardization

c. a control laboritory capable of maintaining product quality

d. a market of sufficient size and variety to provide a source of information on the performance of its products (cements)

e. financial ability to sustain the work involved in membership on an active technical committee (attendance at meetings, laboratory participation in committee research projects, etc.)

f. a promising future to which the company management can look with enthusiasm and confidence

To the SASO Technical Comittee on Cement should be added members from government agencies involved in construction, from responsible building industry companies, from universities, and research institutes and from additional cement companies which may be formed under the new five-year plan, etc.

SASO should, of course, supply the secretariat, the early rules for conduct of committee affairs, and probably the first committee chafrman. I suggest that the ASTM Regulations for conduct of technical committees would be a useful early guide, but in due course the SASO Committee should develop its own rules, scope, schedule of meetings, technical program, etc. - all of course with strong guidance from SASO.

It seems improbable that any other committee similar to the recommended SASO Committee on Cement could be effectively formed in Saudi Arabia, at least until after the new Five Year Plan has begun to give rise to other industries with some of the qualifications of the cement companies listed above. This gives SASO an excellent reason to regard the Cement Committee as an experiment leading to the development of improved future SASO procedures.

An effective technical committee, meeting at suitable intervals and conducting its work with all members in direct contact with each other and rith SAS0, can enormously reduce the amount of auxiliary office work which SASO faces under its present procedures and wilich it can not possibly carry out under current and prospective labor conditions in the Saudi Kingdom. 
2. SASO should make specific plans for a "Saudi Arabian National Laboratory for Metrology and Standards." These plans should be incremental in character, that is, amenable to efficient extension as future industrial needs arise. The first element in the plan should relate to a "Laboratory for Metrology."

Explanation: Metrology in Saudi Arabia is in a stage too primitive to serve the needs of an industrial-urban nation such as is being planned. The foundation of good standardization is adequate metrology. SASO has the legal responsibility for all national metrological services. It cannot fulfill this role without a suitably constructed and equipped laboratory which will take some years to plan, build, staff and bring to effective operation. The present Metrology Section of SASO has several good young men but they need stronger support. A foreign expert in laboratory desion is probably needed.

3. SASO should resist participation in the enforcement of the mandatory industrial standards which it promulgates.

Explanation: This recommendation originates from a question which Dr. Qutb asked me a number of times in various forms.

Note that this recommendation refers only to industrial standards, not to standards on food and drugs with which this Report is in no way concerned.

With regard to Building Codes and Building Reoulations which necessarily include a great many industrial standards, I am convinced that SASO should play only an interpretive and advisory part.

Saudi Arabia is moving vigorously to industrialize its society. All industrial nations have learned that the enforcement of law must be separated from the making of law. This results from the highly detalled and complicated division of responsibilities and the concentrated urbanization which inescapably accompany industrialization. The process is thoroughly documented in the literature of political history and political science.

SASO, as a law-making body ("mandatory standards") should not participate in the enforcement of its standards but must always be well-informed concerning the results of that enforcement by other authorities. One of the most effective means for doing this is for SASO to maintain intimate contacts with the industries and organizations which are directly affected by SASO standards. The "SASO Committee on Portland Cement" which I have suggested earlier in this report would typically be an efficient mechanism for the purpose. 


\section{Acknowledgements}

I record herewith my thanks to the following persons who greatly assisted me in the course of my Saudi Mission:

To Dr. Ahmed H. Qutb, Director General of S.ASO, who provided office facllities for me at SASO and graciously gave me unrestricted access to his staff for purposes of consultation and guidance to Saud 1 Industries, laboratories, etc.

To Dr. Duane C. Butcher of the U.S. Embassy in Jiddah, who extended Embassy office services and transportation assistance to me.

To Mr. Shirl MicArthur of the U.S. State Department in charge of the U.S. Guest House in RIyadh, who repeatedly helped to arrange housing for me under extremely difficult circumstances; Mr. McArthur also gave me invaluable assistance on transportation and communications problems.

To Mr. Hilliam Cavanagh, Managing Director of the American Society for Testing and Materials (ASTM) and to Mr. Willam A. Maples, Fxecutive Director of the American Concrete Institute (ACI), both of whom went to extraordinary effort and expense to be useful to SASO. The American Concrete Institute develops and publishes the world's most widely used groups of standards and codes covering construction in concrete. These standards and codes have been translated into many languages including Arabic. As I studied the situation in Saudi Arabia, it became evident that the most useful standards that SASO could possess at this time (apart from foods and drugs) would be those of ACI and ASTM. In my capacity as past-president of both ACI and ASTM, I wrote from Riyadh to Mr. Cavanagh and Mr. Maples describing SAso's problems and needs. Mr. Maples promptly afr-malled a collection of ACI standards to SASO together with a graclous letter to nr. Zutb offering all possible further assistance. Mr. Cavanagh immediately sent the entire 1975 Edition of all ASTM standards (fifty large volumes) to SASO with the compliments of ASTM. Mr. H. Steffen Peiser, Chief of the Office of International Relations of the Mational Bueau of Standards, arranged for this shipment of ASTM books to be transported through expedited U.S. Government channels.

To Mr. Donald Peyton, Executive Director of the American National Standards Institute (ANSI) go my warm thanks for promptly sending to SASO, at my written suggestion from Riyadh, a complete up-to-date set of AVSI standards, a truly huge compendium of industrial technical information. SASO, before my arrival in Riyadh, had made attempts to purchase all ANSI standards but because of misunderstanding of ANSI operations had not made their requirements clear to A.NSI. On my 
written explanation to Mr. Peyton he took typically quick and comprehensive action.

As directors of outstanding American private organizations Messrs. Peyton, Cavanagh, and Maples have given extraordinary and understanding assistance to the U.S. Government agencies which are concerned with maintaining cordial and heloful relations with Saudi Arabia. These three men and their respective organizations deserve the thanks of those agencies.

Full and invaluable administrative support of my mission was provided by the National Bureau of Standards. I acknowledge especially the counselling by Dr. Brady and Mr. Peiser. Mrs. Doris Bluebond undertook the arduous task of reading this entire report in my original long hand script and thereafter making a typed copy of it. 
Append ix

Kingdom of SAUDI ARABIA

A GUIDE TO

The Procedures, Formulation and Editing of Saudi Standards

PART ONE

A Guide to the Procedures of Saudi Standards

Preparation

Saudi A-rakean Strularils Organization 
AYPENDIX AS SUPPLIED TO THE AUTHOR BY THE SAUDI ARABIAN STANDARDS ORGANIZATION

The following procedures, which have been established by SASO, are mainly intended to manage the Organization's technical work

satisfactorily, and to carry out the measures and steps to te adopted by the technicians of the various sections in a standardized form, so as to issue the standards in the most suitable form.

One or more of these procedures may be overstepped according to the type of the standard. Also, some of them can be carried out simultaneously in a certain standard, while, in the same time, some other procedures are being taken in another draft standard.

\section{Stage of Collecting Information}

(1) Under the supervision of the dominating department, each section shall write to the concerned bodies such as ministries, organizations, governmental departments, universities, laboratories, research centers, factories, commercial and industrial chambers, the Kingdom's commercial attaches working in the Kingdom (through the Ministry of Foreign Affairs), requesting provision of any data, research or reports relating to the standards included in SASO approved program of work. For the same purpose, contacts with any of these bodies shall take place, if necessary. In the meantime SASO can be in touch with these concerned bodies at the stage of the preparation of each draft standard privately.

(2) Under the supervision of the dominating department, each section shall determine priorities of executing the annual program to be approved by the Director General after defining the exact titles of the standards and the proposed date for commencing formulation of each one in the light of the number of the staff working in the section.

(3) All the available Arabic, foreign and international standards, other reference books or data relating to the standard under preparation shall be studied as follows:

a. refer to the available publications containing standards indexes to collect the titles of the suitahle standards (national or international)

h. get the catalogues relating to the draft standard from local resources

c. refer to as many standards as you possibly can

d. refer to ISO, ASYO, and IFC standards and any other international documents, and also to the 


\section{international recommendations and draft standards \\ e. refer to as many of the other reference books as you possibly can \\ f. write to foreign agencles requesting provision of any additional information}

(4) Prepare a list of the existing, local factories and any other bodies in which field studies have to be carried out for the standard under preparation, explaining the need for and the purpose of such field studies.

(5) A list of the detailed items ought to be included in the standard, in addition to the statement of the characteristics which ought to be standardized, the required quality standard and whether these items will be directly or indirectly specified mentioning the necessary tests, if any.

(6) Prepare a file containing copies of all the available scientific data above mentioned in items 1 and 3. As for the data, coples of which are difficult to get, and the big reference books containing methods of test and analysis, it is enough to make an accurate summary of the subject and keen it, accompanied with the names of the reference books.

(7) Prepare a brief report containing an outline of the results attained concerning the aforementioned stage, to be annexed with a comparative table showing the information mentioned in other various standards and reference books.

\section{Stage of Field Studies}

The section shall prepare a schedule about the field studies necessary for all the standards included in SASO work program, to be distributed, in coordination, between the staff of the section. The stage of field studies shall include the following -

(1) Visits to existing local factories to seek to know:

a. the local standards applied in production and any other data or research relating, to the draft standard

b. quality standard and methods of control

c. avallability of laboratory facilities and tests carried out on the factory's products, and getting the results of some of these tests, if any 
d. the problems facing production, and any other affairs concerning the draft standards

(2) Visits to other bodies, to be defined above, particularly including the following -

Laboratories

The studies to be carried out shall include the following points:

a. available laboratory factlities

b. applied methods of test

c. getting the results of some of the tests carried out on the commodity under study, and any other affairs

(3) Commercial and Industrial Chambers and Local Markets

The visits to these places shall include the following:

a. to hold meetings with the responsible people in the concerned bodies, and study the local markets

b. to collect any available data about the main bodies in the importing countries

c. to correspond with companies, commercial attachés or any other concerned bodies, inside the Kingdom or abroad, if necessary

d. to collect data about any problems facing importation, and any other affairs concerning the draft standard

Withdraw samples for analysis, if necessary, and be sure that no additional items are needed for the draft standard. Field studies shall firstly commence in Riyadh, then in the other cities, if necessary, which shall be subject to the Director General's agreement, after explaining the purpose of the proposed visits.

A detailed report shall be prepared about each visit. At the end of this stage, a comprehensive report shall be submitted containing the following, points:
a. Status of existing factories
b. locally avallable laboratory facilities 
c. the bodies responsible for the implementation control

d. problems facing manufacturing, importation and exportation

e. possibility of obligation with the whole staniard or with part of it

All data and reports shall be kept in the file of the standard.

3. Preparation of Preliminary Draft Standard

(1) In the light of the aforementioned studies, a preliminary draft standard shall be prepared according. to the "Guide to Formulation of Standards."

The draft standard shall not contain any informative data about methods of manufacture, unless necessary for the final commodity to meet the requirements of the standard.

The following shall be taken into account in preparing the draft standard:

a. The draft standard shall contain all the required items. The limits permissible in these items shall not be harmful to the consumer's health and safety.

b. The limits of the 1tems dealing with quality standards shall go along with the local needs, so as to allow importing only the commodities, suitable for the purpose of their use, wherever they come from, and to stop importing unsuitable commodities, wherever they come from. Local products, if any, shall be taken into consideration in order to raise their quality. In some cases, and without causing any harm to the consumer's health and safety, certain requirements for locally manufactured commodities, and other different requirements for imported commodities may be deliberately stated, to avoid any difficulties that might rise at implementation.

(2) The following shall be taken into account in preparing standards for products and commodities:

a. Availability of the necessary methods of tests and analysis.

b. Issuance of the methods of test or analysis in a 
separate standard. In case there are some general methods of test or analysis which are common for a number of similar commodities, in addition to some other methods for the commodity under study, a separate draft standard for the common general methods shall be prepared, while the other specific methods shall be included in the standard of the commodity itself.

c. The draft standard for the commodity stıall include an item dealing with sampling. The draft standard for the methods of test or analysis shall include the way of sample preparation in the laboratory. Both may be stated in one standard.

(3) The concerned section shall prepare a preliminary translation into English for the draft standard including at least a list of technical terms. This translation shall be passed, through the dominating department, to the translation section accompanied with any reference books or standards that might help in the process of translation. Then, the English version shall be returned to the concerned section, through the dominating department, to check the corrections of the technical contents. The (translation section) is the one accountable for the English version of the draft standard.

(4) The draft standard shall be widely circulated on ministries, governmental departments, organizations, and other concerned bodies such as commercial and industrial chambers, local factories, commercial attache's and consulting firms in the Kingdom, to submit their views and comments within a period of two months. This period may be extended according to request of the section, which has to give an explanation for such request. The section shall be responsible to inform the concerned bodies with the standard contents, through providing each of them with a copy of the draft standard. The section shall also publicize the issuance of the standard so as to enable any overstepped concerned body to ask for a copy.

\section{Collection of Technical Views and Comments}

The views and comments submitted about the draft standard shall be collected and arranged in tables including, the item, the views or comments submitted about it, the reaction of the concerned section (whether acceptance or refusal of the views, explaining the reason for this) and the views obtained from the meetings held to get to know various points of view.

The views or comments which may lead to technical or economical problems shall be submitted to the Director General. 


\section{Formation of Technical Committees}

(1) The concerned section shall offer a proposal to form a technical committee to study the draft standard and the views and comments submitted from the concerned bodies. Such a committee shall comprise of representatives from the following bodies:
a. factories and other bodies intended for application
b. the consumer protection department (to be permanently represented in all the comiltees)
c. bodies submitting essential views or comments
d. research centers and universities

(2) The following shall be taken into account, in the meetings of the technical comittee:

a. The discussions shall be confined in technical problems only, as SASO is concerned with the draft finalization.

b. Should SASO representative perceive that a certain amendment will be harmful to the consumer's health or safety or to the national interest, or will have a dire effect on the commodity situation in the Kingdom, he shall insist to record his perception very clearly and deliberately in the minutes, and submit a separate explanatory memorandum about the matter to the Director General.

c. All the members of the committee shall sion the minutes, in which all the changes that occured to the SASO draft standard shall be mentioned, with the following steps taken into consideration:

(a) a draft of minutes shall be prepared and signed by all the members in the meeting itself

(b) the minutes shall be typed in enough coples, and be signed by the members from outside Riyadh in the same meeting, if possible

(c) after typing the minutes in the final form, it is preferable to have member's signatures on all its pages 
6. Fina1 Distribution

(1) The concerned section shall refer the final form of the draft standard to the formulation committee assigned by the Director. General, to review and take the ncessary measures.

(2) Then the draft standard shall be referred to the legal advisor to make sure that its items are in agreement with the functions stipulated in the organization's constitution.

In both cases the concerned section shall have to fully cooperate with the formulation comittee and the legal advisor, provide them with any required information or data and to make sure of the corrections of the technical content of the draft standard.

(3) The concerned section shall keep a final copy of the draft standard with all its pages carrying the signature of the responsibilities in the section, the formulation comittee and the legal advisor.

(4) The Engish version of the draft standard shall be accordingly ammended.

(5) The final Arabic and English versions of the draft standard shall be circulated, according to subject matter, to the laboratories of the Ministry of Health, the Ministry of Agriculture, and the Public Works Department. Copies of these versions shall be regularly sent to both the industry and the consumer's protection departments in the Ministry of Commerce and Industry. Also they shall be sent to the research and industrial development center and to other concerned bodies. Members of the board of directors shall get two copies of each draft standard to determine the possihilities of application and obligation. The comments of these hodies are to be recelved within three months and the fallure to send a reply by that date shall be considered an approval of the draft standard concerned.

(6) Publicity for the draft standard shall be made in different news media.

(7) After the lapse of the set period, the concerned section shall prepare a memorandum containing coments received and the section's views about them either in acceptance or rejection with reasons given and whether there is need to hold a meeting for a specialized technical committee to study them.

(8) In case the need arises to hold a meeting for a specialized technical committee, a representative of the concerned body that sent the comments, shall be invited to participate in the committee's work. A final decision about these comments shall be 
taken within a month after the lapse of the three months period mentioned in item 6 , number 5 .

(9) The ammended items shall be referred again to the formulation committee and the legal advisor for final revision.

7. Submission to the Board of Directors

After these steps, the draft standard is considered to be in the final form. Three signed coples of that draft shall be kept. One of these copies is kept in the concerned section, while the two other copies are directly sent to the Director General after the execution of 1 tem 6 , number 9. He shall refer them together with the relevant report and memorandum to the Board of Directors for adoption. The report must include any fundamental comments subject to dispute together with an explanation of the organization's views and reasons.

The memorandum must state whether the draft standard shall be partially or completely a mandatory one and the suggested period for enforcement after it is published in the official gazette.

\section{Publication of the Standard}

(1) After the draft standard is adopted, three authorized coples, signed from the concerned section, shall be prepared. One of these coples shall be kept in the special file of the subject, the other sent to the Director General while the third is sent to the official gazette for publication. The period after which the standard shall be enforced in accordance with the Board of Director's decision, shall be defined.

Then the concerned section shall:

(2) Publicize the necessary information about the issued standard through various news media.

(3) Inform the various bodies on the publication of the standard in the official gazette, while providing the concerned bodies with a copy of the standard under publication.

(4) Revise the text published in the official gazette and address the publishing house in case misprints are found, to make the appropriate corrections.

(5) Inform the various bodies of the publication date in the official gazette with reference to any misprints.

(6) Read the first printer's proofs of the standard as well as a 
copy of the final printed standard. If there are any misprints in the final copy, a list of these mistakes shall be prepared, while taking the necessary steps to print corrections and attach them to the standard.

\section{Implementation Follow-up}

The concerned section shall follow up the implementation of the standard through the following steps:

(1) Ask the concerned bodies and laboratories to present regular reports showing implementation steps, giving a summary of achieved results of tests, stating the rate of tested commodities conforming with the standards and the percent of accepted and rejected comodities.

(2) If necessary, hold meetings between the organization and merchants, business and industry men and other concerned bodies to discuss any problems related to standards.

(3) In case any comments are received, the concerned section shall study them to decide whether there is a need to revise the standard either by raising or lowering the value of quality limits. It shall prepare a memorandum, to the Director General, containing, the sections views, whether there is need to call a meeting for a technical committee and the possibility of referring the matter directly to the Board of Directors. The concerned section shall take, in this case, the necessary steps to submit the subject to the Board of Directors, publish it in the official gazettee and inform the concerned bodies according to the set rules.

(4) In all cases the concerned section shall review the standard every three years and report to the Director General on whether there is a need to revise the standard together with the necessary measures in this report.

(5) In case of any ammendments added to any of the items of the standard, an appendix shall be prepared. As for the full revision, the standard shall be reprinted. 


\begin{tabular}{|c|c|c|c|}
\hline $\begin{array}{l}\text { U.S. DEPT. OF COMM. } \\
\text { BIBLIOGRAPHIC DATA } \\
\text { SHEET }\end{array}$ & $\begin{array}{l}\text { 1. IPIBIIL ATION (OR RIIPORT NO. } \\
\text { NBSIR 75-976 }\end{array}$ & $\begin{array}{l}\text { 2. Gov'e Acciossion } \\
\text { No. }\end{array}$ & 3. Recipicnt's Acecssion No. \\
\hline \multirow{2}{*}{\multicolumn{3}{|c|}{$\begin{array}{l}\text { 4. TITI.I: ANI) SIITITI.1: } \\
\text { STANDARDS AND MEASUREMENT CAPABILITIES IN THE KINGDOM OF } \\
\text { SAUDI ARABIA }\end{array}$}} & $\begin{array}{l}\text { 5. Publication Date } \\
\text { January } 1975\end{array}$ \\
\hline & & & 6. Performing Organization Code \\
\hline \multicolumn{3}{|c|}{ 7. AUTHOR(S) Dr. A. Allan Bates } & 8. Performing Organ. Report No. \\
\hline \multicolumn{3}{|c|}{$\begin{array}{l}\text { 9. PERFORMINC } \text { OR(IANIZATION NAME ANI) ADIDRESS } \\
\text { NATIONAL BUREAU OF STANDARDS } \\
\text { DEPARTMENT OF COMMERCE } \\
\text { WASHINGTON, D.C. } 20234\end{array}$} & 10. Project/Task/Work Unit No. \\
\hline \multicolumn{3}{|c|}{$\begin{array}{l}\text { 12. Sponsoring Organization Name and Complete Address (Street, City, State, ZIP) } \\
\text { U.S.-Saudi Arabian Joint Working Group on Industrialization } \\
\text { of U.S.-Saudi Arabia Joint Commission } \\
\text { National Bureau of Standards, Washington, D.C. } 20234\end{array}$} & $\begin{array}{l}\text { 13. Type of Report \& Period } \\
\text { Covered } \\
\text { Fina } 1 \text { report } \\
\text { 14. Sponsoring Agency Code }\end{array}$ \\
\hline
\end{tabular}

15. SUPPLEMENTARY NOTES

16. ABSTRACT (A 200-word or less factual summary of most significant information. If document includes a significant bibliography or literature survey, mention it here.) The Saudi Arabian Standards Organization (SASO) is operating under uniquely difficult circumstances. Basic sources of difficulties are: 1 ) almost total lack of any industries for consultation and cooperation, 2) extreme speed at which Saudi Arabia is attempting transformation into an urban-industrial state, 3) unavailability of well-trained indigenous Saudi personnel, either scientific-technical or secretarial-clerical, and 4) lack of SASO laboratory facilities for standardization research work.

Operating procedures which SASO has adopted are based on consensus principles utilized in countries with advanced industrial economies. Such procedures are not now applicable in Saudi Arabia. Only the Saudi Portland Cement industry now offers opportunity for consensus standardization.

Until industrialization has advanced in the Kingdom SASO should use Interim Procedures to produce Tentative Standards for national use. The Interim Procedures should permit direct and immediate adoption of necessary standards from reliable national and international sources with minimum modification. The nature and terms of use of Tentative Standards must be defined for public understanding.

SASO should not play the central role in the enforcement of SASO standards. SASO should have an advisory relationship with authorities charged with mandatory standards enforcement. SASO should not now undertake the development of a national Saudi building code, although it must produce the standards upon which a building code may be promulgated by a related agency appointed for that purpose.

17. KEY WORDS (six to twelve entries; alphabetical order; capitalize only the first letter of the first key word unless a proper name; separated by semicolons)

Building codes; industrialization; less-developed country; SASO; Saudi Arabia;

standardization; tentative standards

18. AVAILABILITY

For Official Distribution. Do Not Release to NTIS

\begin{tabular}{|c|c|}
\hline $\begin{array}{l}\text { 19. SECURITY CLASS } \\
\text { (THIS REPURT) }\end{array}$ & 21. NO. OF PAGES \\
\hline UNCL ASSIF IED & 36 \\
\hline $\begin{array}{l}\text { 20. SECURITY CLASS } \\
\text { (THIS PAGE) }\end{array}$ & 22. Price \\
\hline UNCLASSIFIED & $\$ 4.00$ \\
\hline
\end{tabular}





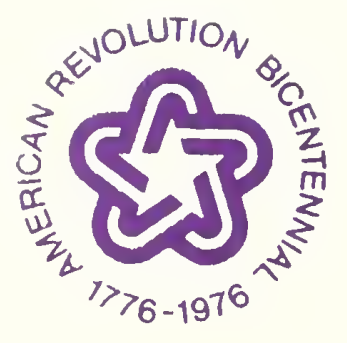





